\title{
Axial load tests on large diameter bored piles in very dense sands
}

\author{
Nabil F. Ismael
}

\begin{abstract}
With increased population and economic development, many towers and high rise buildings are being constructed in Kuwait city. The large applied loads required the construction of deep pile foundations or piled raft systems. For one structure consisting of 60 stories and 3 basements, large diameter bored piles were employed. The axial capacity in tension and compression, and the load transfer mechanism were examined by field tests. Testing included one tension test on a 0.8 $\mathrm{m}$ diameter, $20 \mathrm{~m}$ long bored piles, and a compression test on a $1.5 \mathrm{~m}$ diameter, $35 \mathrm{~m}$ long pile. The piles were installed in very dense sands below the water level and testing was carried out to failure. Other tests included borings to $70 \mathrm{~m}$ deep, sampling and Standard Penetration Tests. Laboratory tests were carried out to determine the basic soil properties included gradation, and plasticity tests for soil classification. From the pile load test results, the side friction, and base resistance were determined and correlated with the Standard Penetration Resistance values as determined from the boreholes. Comparison between the present tests and previous tests were made and the foundation design parameters were calculated. The deformations at maximum loads were $2.6 \%$ and $1.9 \%$ for the piles in tension and compression respectively. The frictional resistance for the tension pile reached $156 \mathrm{kPa}$, while the pile in compression required large settlement to reach bearing capacity failure.
\end{abstract}

Keywords-bored piles, axial load tests, very dense sands, side friction, base resistance.

\section{Introduction}

Large diameter bored piles are increasingly used in Kuwait and the gulf states as foundations for heavy towers, or as part of raft on piles system. These structures may consist of up to 100 stories and 4 basements below ground level. The piles have a diameter ranging from 0.8 to $1.5 \mathrm{~m}$ and a length of up to $40 \mathrm{~m}$. They have the advantage of easy and economic installation, and large axial and lateral load carrying capacity.

Several field tests were carried out to determine the axial capacity of these piles in tension, and compression, and the load transfer mechanism. The most important parameters included the ultimate side friction and base resistance. The tests reported included driven piles (Ismael 1989, Ismael 1999) and bored piles. Tests on bored piles involved tension tests on $0.5 \mathrm{~m}$ piles (Ismael \& Al-Sanad 1986), compression tests on $1.2 \mathrm{~m}$ diameter instrumented (Ismael \& Farraj 2014) and on short piles of diameter ranging from 0.45 to $1.2 \mathrm{~m}$ (Ismael 2004). However, additional tests are required to reach

Nabil Fathy Ismael, Professor

Civil Engineering Department, Kuwait University

Kuwait definitive conclusions with respect to the side friction and the base resistance of these piles and consequently the allowable capacity for use in engineering design.

This paper presents the results of recent field tests carried out on two large diameter bored piles in very dense sands under axial loading. One pile $0.8 \mathrm{~m}$ diameter and $20 \mathrm{~m}$ long was tested in tension, and the second pile $1.5 \mathrm{~m}$ diameter and $35 \mathrm{~m}$ long was tested in compression. Soil conditions and ground water levels were determined by borings and sampling to a depth of 50 to $70 \mathrm{~m}$. The results were analyzed and important design parameters were determined. These results were compared with the analytical predictions and with previous test results for the benefit of the geotechnical design engineers and researchers.

\section{Soil Conditions and Pile Installation}

Figure 1 shows a brief summary of the soil profiles and the dimensions of the test piles. The soil profile consists of very dense fine to medium grained silty sand along and below the base of the piles. Slight or weak cementations or cemented lumps exist in this deposit. Boring and sampling was carried out to a depth of $70 \mathrm{~m}$. The average standard Penetration Test SPT $N$ values were 125 blows/ $0.3 \mathrm{~m}$ along the pile shaft and $>100$ blows $/ 0.3 \mathrm{~m}$ below the base. The excess of evaporation over rainfall even in the winter season leads to the precipitation of cementing agents such as carbonates and sulphates in the soil matrix and the formation of cemented layers. Pile 1 is $0.8 \mathrm{~m}$ diameter and $20 \mathrm{~m}$ long. Pile 2 is $1.5 \mathrm{~m}$ diameter and $35 \mathrm{~m}$ long. Prior to pile installation the ground was excavated to a depth of $\sim 18 \mathrm{~m}$ and ground water was lowered $1 \mathrm{~m}$ below the lowest excavation level.

The piles were installed by drilling using a steel casing for the full length of the piles. The steel cage was installed by placing it in the hole followed by concreting. The casing was removed upon concreting.

\section{Pile Testing}

Figure 1 shows the test piles. The tension pile was tested in accordance with ASTM standard 3689-83 (American Society for Testing and Materials 1994). The load was carried out to $250 \%$ of the working load. The working load is 3200 $\mathrm{kN}$ (326 ton), and the corresponding movement was $4.7 \mathrm{~mm}$. The test set up is shown in Figure 2. It included 4 compression piles for reaction, and four jacks each having a 
400 ton capacity. Deformation was measured by dial gages mounted on reference beams.

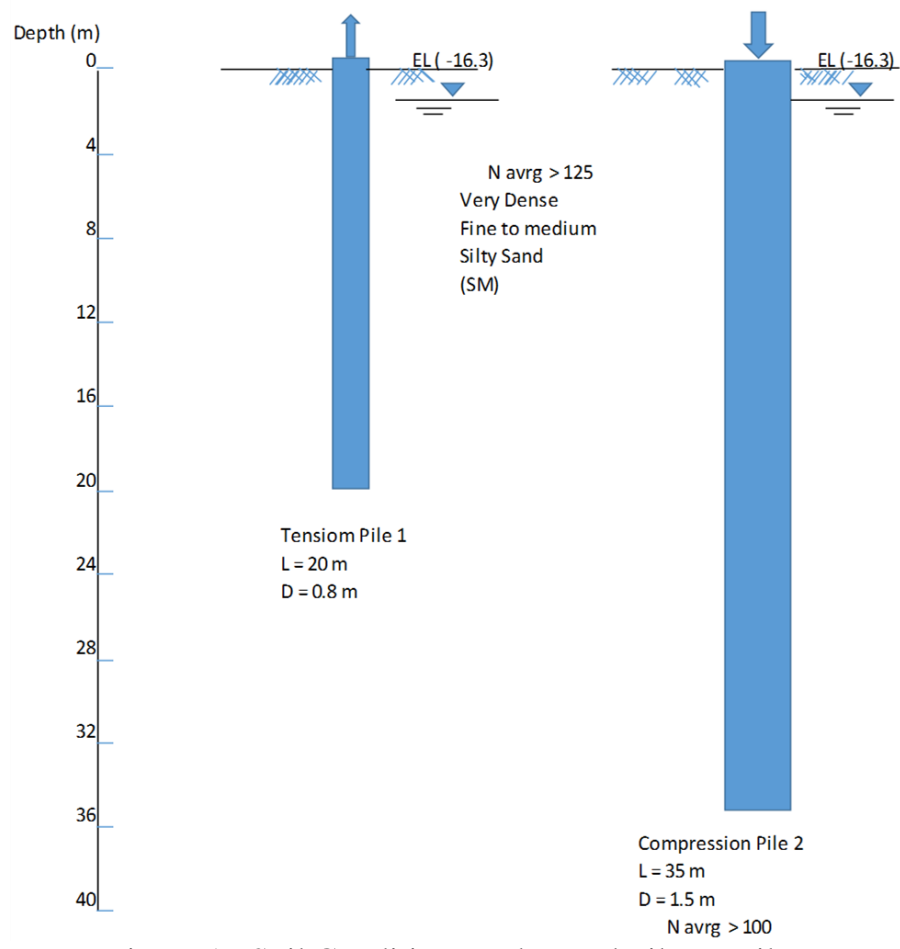

Figure 1. Soil Conditions and Bored Pile Details

The compression pile 2 was tested in accordance with ASTM standard D 1143. The load was similarly carried out to $250 \%$ of the working load. The working load is $17000 \mathrm{kN}$ (1733 ton), and the corresponding settlement was $6.88 \mathrm{~mm}$. The test assembly consisted on three Jacks each having a 2000 ton capacity and 24 anchors as shown in Figure 3. The maximum load reached was $42500 \mathrm{kN}$ (4335 tons). Deformation of the pile during the test was monitored by dial gages. The test equipment and the test setup were provided by Kuwait Bruckner Construction Contracting Company, Kuwait.

For both piles failure was progressive in nature, and the failure load was taken by the slope tangent method at the intersection of the initial tangent and the final tangent to the load movement curve. For the tension pile this was at the maximum load reached. From a soil engineering stand point, this load is less than the load causing ultimate failure. Figures 4 and 5 show the load-displacement curves for the test piles. The vertical arrows in the figure indicate the failure load.

\section{Analysis of Test Results}

\section{A. Tension Test 1}

The average frictional resistance along the pile shaft was calculated from:

$$
f_{s}=Q_{u}-w^{l} / \pi D L
$$

where,

$$
\begin{array}{ll}
\mathrm{f}_{\mathrm{s}} & \text { average frictional resistance } \\
\mathrm{Q}_{\mathrm{u}} & \text { ultimate load in tension } \\
w^{t} & \text { effective weight of the pile } \\
\mathrm{D} & \text { pile diameter } \\
\mathrm{L} & \text { pile length }
\end{array}
$$

Substituting $8000 \mathrm{kN}$ for $\mathrm{Q}_{\mathrm{u}}, 0.8 \mathrm{~m}$ for $\mathrm{D}, 20 \mathrm{~m}$ for $\mathrm{L}$, $23.5 \mathrm{kN} / \mathrm{m}^{3}$ for the unit weight of the reinforced concrete pile, $\mathrm{f}_{\mathrm{s}}$ is determined at $156 \mathrm{kN} / \mathrm{m}^{2}$. This compares very well with previous compression tests on two $1.2 \mathrm{~m}$ diameter instrumented bored piles in very dense sand where $f_{s}$ was 158 $\mathrm{kN} / \mathrm{m}^{2}$ for the $25 \mathrm{~m}$ long pile and $185 \mathrm{kN} / \mathrm{m}^{2}$ for the $18 \mathrm{~m}$ long pile (Ismael and Farraj 2014).

A close examination of Figure 4 reveals that the failure was progressive in nature. At the maximum load reached the pile movement was $20.52 \mathrm{~mm}$ or $2.56 \%$ of the pile diameter. Additional load could have been applied until the pile starts to move continuously at no increase in load.

The ultimate uplift load is related to the effective overburden pressure by

$$
Q_{u}=\frac{1}{2} \gamma^{t} L^{2} \pi D K_{u} \tan \phi^{t}+W^{t}
$$

in which $Q_{u}=$ ultimate uplift load, $\gamma^{\prime}=$ effective unit weight of the soil, $\mathrm{K}_{\mathrm{u}}=$ coefficient of lateral earth pressure in uplift; $\phi^{\theta}=$ effective angle of shearing resistance and $\mathrm{L}, \mathrm{D}, W^{t}$ are as defined before.

Substituting $\gamma^{\theta}=\gamma_{\text {sat }}-\gamma_{W}=9.81 \mathrm{kN} / \mathrm{m}^{2}$, and $\phi^{\phi}=43^{\circ}$ employing the empirical relation between $\mathrm{N}$ and $\phi^{b}$ (Peck, Hanson and Thornburn 1974), $\mathrm{K}_{\mathrm{u}}$ is obtained as 1.7.

\section{B. Compression Test}

Figure 5 shows the load-settlement curve of the compression pile. The extrapolated failure load is shown by the first vertical arrow as determined by the slope tangent method as $48000 \mathrm{kN}$. Assuming that the frictional resistance $\mathrm{f}_{\mathrm{s}}$ for the compression pile is identical to the tension pile, i.e. $f_{s}=156$ $\mathrm{kN} / \mathrm{m}^{2}$. The base resistance $q_{p}$ is determined as

$$
q_{p}=\left(Q_{\text {uit }}-Q_{s}\right) / A_{p}
$$

where $Q_{\text {ult }}, Q_{s}$ are the ultimate or failure load, $Q_{s}$ is the ultimate load carried out by shaft friction, $A_{p}$ is the base area with diameter $1.5 \mathrm{~m}$. on this basis $q_{p}$ is calculated as 12.56 $\mathrm{MPa}$. This is larger than previous values reported for shorter piles (Ismael and Farraj 2014) where $q_{p}$ was $8.74 \mathrm{MPa}$ for the $1.2 \mathrm{~m}$ diam, $25 \mathrm{~m}$ long pile and $4.33 \mathrm{MPa}$ for the $1.2 \mathrm{~m}$ diam, $18 \mathrm{~m}$ long pile.

A close examination of Figure 5 reveals that the failure was progressive with a settlement of $22.92 \mathrm{~mm}$ at the maximum applied load of $42500 \mathrm{kN}$. At the failure load considered of $48000 \mathrm{kN}$ the extrapolated settlement is $29 \mathrm{~mm}$ or $1.93 \%$ of the pile diameter. 
Proc. of the Sixth Intl. Conf. Advances in Civil, Structural and Mechanical Engineering - CSM 2018 Copyright $(\odot)$ Institute of Research Engineers and Doctors, USA. All rights reserved.

ISBN: 978-1-63248-150-4 doi: 10.15224/978-1-63248-150-4-26

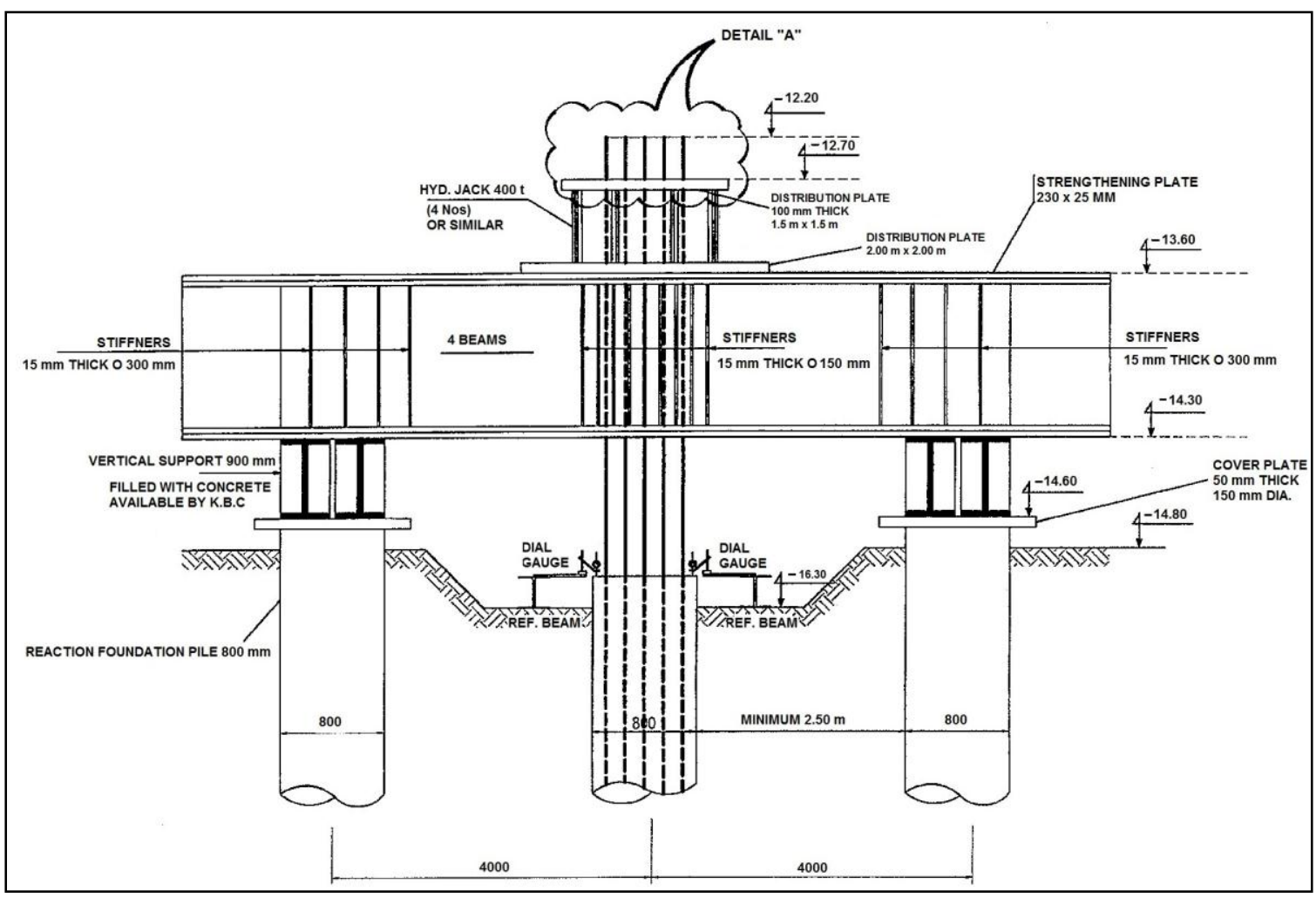

Figure 2. Tension Test Setup

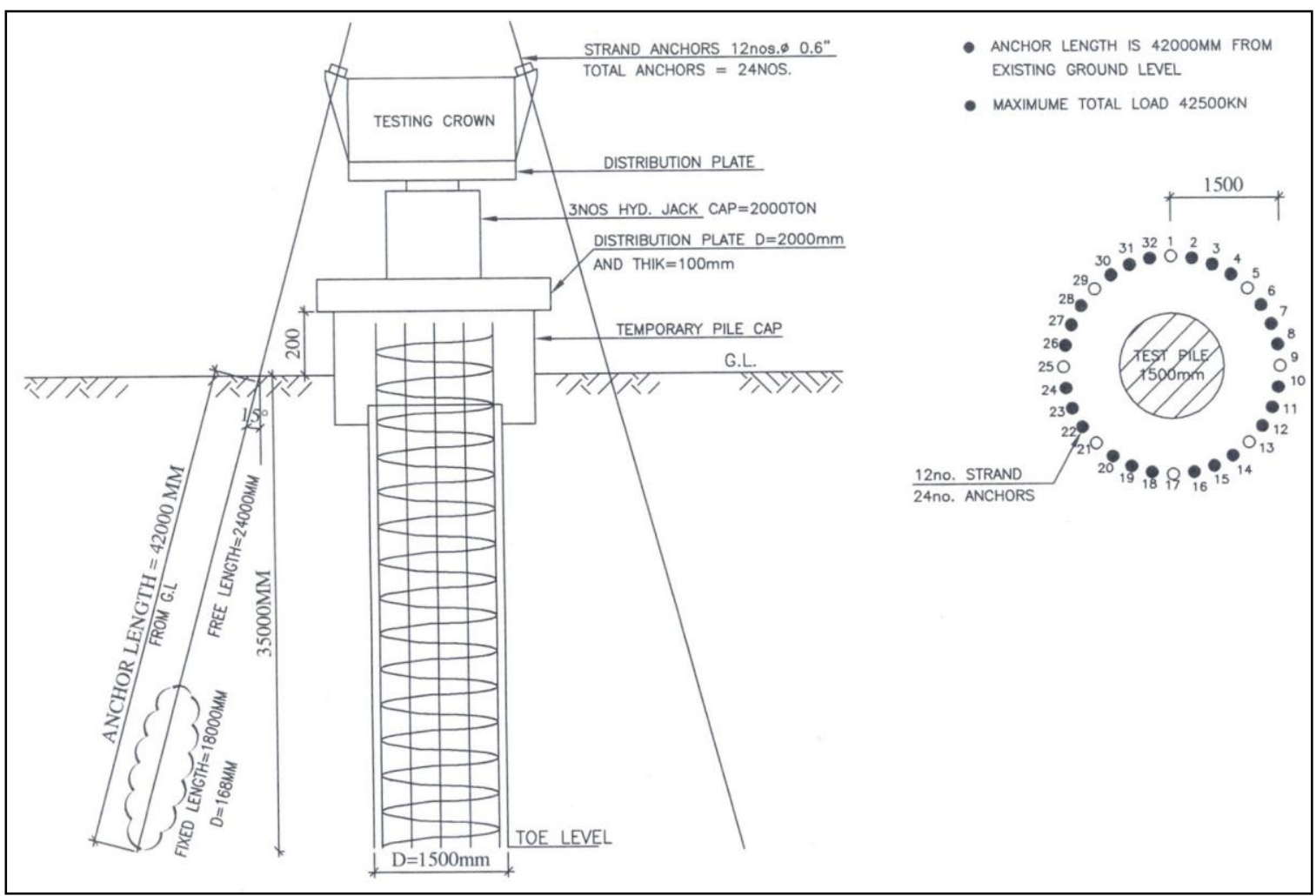

Figure 3. Compression Test Setup 


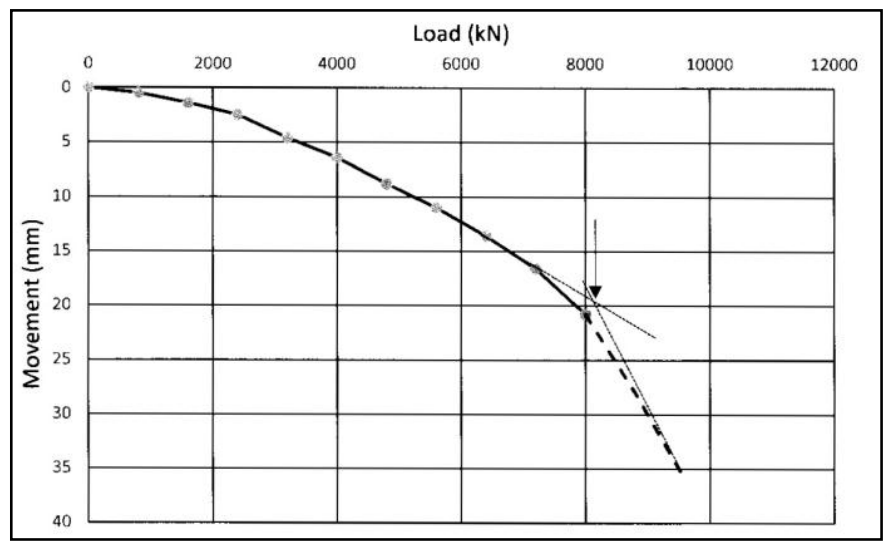

Figure 4. Load-Movement for the Tension Pile 1, Dim 800 mm., L $=20 \mathrm{~mm}$

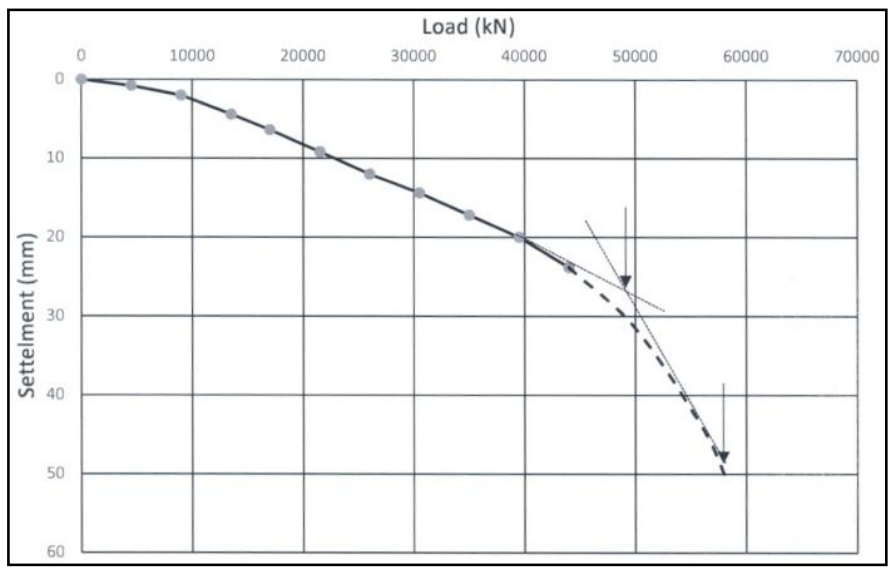

Figure 5. Load Settlement Curve for the Compression Pile 2

\section{v. Discussion}

\section{A. Side Friction}

According to Meyerhof (1976), the side friction $f_{s}$ is calculated as:

$$
f_{s}=\bar{N} / 100 \text { tsf }=0.96 \bar{N} \mathrm{kN} / \mathrm{m}^{2}
$$

where $\bar{N}$ is the average standard penetration test SPT-N value along the pile shaft in the bearing stratum.

For Pile $1, \bar{N}$ is 125 along the pile shaft and is taken as the average value from 5 boreholes. Substituting in Equation 4 $\mathrm{f}_{\mathrm{s}}$ is calculated as $120 \mathrm{kN} / \mathrm{m}^{2}$. This is lower than the measured value of $156 \mathrm{kN} / \mathrm{m}^{2}$. Similar findings were reported by (Ismael and Farraj 2014). This is attributed to the fact that Meyerhof Method is conservative and leads to lower values.

\section{B. Base Resistance} (1976):

$$
\mathrm{Q}_{\mathrm{b}}=0.4 \mathrm{~N} \mathrm{~L}_{\mathrm{b}} / \mathrm{D} \leq 4 \mathrm{~N} \operatorname{tsf}(0.383 \mathrm{~N} \mathrm{MPa})
$$

where, $\mathrm{L}_{\mathrm{b}}$ is the embedded pile length in the bearing stratum, $\mathrm{N}$ is the average value of the standard penetration value near the pile base.

Using $\mathrm{N}$ value of 100 in the above equation the base resistance is calculated as $38.3 \mathrm{MPa}$ compared to the measured value of $12.56 \mathrm{MPa}$. This is about 3 times larger. Using $\mathrm{N}=$ 50 , the calculated base resistance is $19.15 \mathrm{MPa}$ which is still larger than the measured value. Examination of Figure 5 indicate that the pile can resist additional loads beyond the designated failure load. If the extrapolated ultimate failure load of $58000 \mathrm{kN}$, defined by the second arrow on the right (Figure 5) is considered the base measured resistance will be 18.22 $\mathrm{MPa}$ which is comparable to the calculated value of 19.15 MPa based on $\mathrm{N}$ value $=50$.

\section{vi. Other Remarks}

For the large diameter long bored piles and the very dense soil conditions considered, the piles will act as friction piles with more load taken by side friction compared with base resistance. For the present compression pile $54 \%$ of the load was taken by friction and $46 \%$ by base resistance at failure. A summary of the measured and calculated parameters from the present tests is given in Table 1. A comparison between the present tests and two previous case studies is given in Table 2.Both the measured and calculated values of $f_{s}$ and $q_{p}$ are given for the possible use of the geotechnical design engineers and researchers.

An examination of Table 2 reveals that the measured friction $f_{s}$ along the pile shaft substantially exceeds the calculated values and it is about $150-160 \mathrm{kN} / \mathrm{m}^{2}$ for the very dense silty sand deposits. On the other hand the measured base resistance is smaller than the calculated values even if $\mathrm{N}$ is limited to a maximum value of 50 blows $/ 0.3 \mathrm{~m}$.

\section{Conclusions}

Two large diameter bored piles installed through very dense fine to medium silty sand were tested under axial loading. One pile was tested in tension and the other in compression to failure. The results were analyzed and compared with the calculated values. The following conclusions were reached:

1. For the tension pile, the average side friction $\mathrm{f}_{\mathrm{s}}$ at failure was $156 \mathrm{kN} / \mathrm{m}^{2}$.

2. For the compression pile $54 \%$ of the load was transferred in side friction and $46 \%$ in base resistance at failure. The base resistance $\mathrm{q}_{\mathrm{p}}$ at failure was $12.56 \mathrm{MPa}$. 
Proc. of the Sixth Intl. Conf. Advances in Civil, Structural and Mechanical Engineering - CSM 2018

Copyright (C) Institute of Research Engineers and Doctors, USA. All rights reserved.

ISBN: 978-1-63248-150-4 doi: 10.15224/978-1-63248-150-4-26

Table 1. Summary of Present Test Results

\begin{tabular}{|c|c|c|c|c|c|c|c|}
\hline Test & $\begin{array}{c}\text { Pile } \\
\text { dimensions }\end{array}$ & $N_{\text {value }}$ & $\begin{array}{c}\text { Soil } \\
\text { conditions }\end{array}$ & $\begin{array}{c}\mathbf{f}_{\mathrm{s}} \\
\text { measured } \\
\mathbf{k P a}\end{array}$ & $\begin{array}{c}\mathbf{f}_{\mathrm{s}} \text { predicted } \\
\mathbf{k P a}\end{array}$ & $\begin{array}{c}\mathrm{q}_{\mathrm{p}} \\
\text { measured } \\
\mathrm{MPa}\end{array}$ & $\begin{array}{c}\mathrm{q}_{\mathrm{p}} \\
\text { predicted } \\
\mathrm{MPa}\end{array}$ \\
\hline Tension & $\begin{array}{c}0.8 \mathrm{~m} \text { diam, } \\
20 \mathrm{~m} \text { long }\end{array}$ & \multirow[b]{2}{*}{$\begin{array}{c}125 \text { along } \\
\text { shaft }>100 \\
\text { below base }\end{array}$} & \multirow{2}{*}{$\begin{array}{l}\text { Very dense } \\
\text { fine to } \\
\text { medium silty } \\
\text { sand }\end{array}$} & 156 & 120 & -- & -- \\
\hline Compression & $\begin{array}{c}1.5 \mathrm{~m} \text { diam., } \\
35 \mathrm{~m} \text { long }\end{array}$ & & & $156^{*}$ & -- & 12.56 & $\begin{array}{c}19.5 \\
(\mathrm{~N}=50) \\
38.3(\mathrm{~N}= \\
100)\end{array}$ \\
\hline
\end{tabular}

*Assumed equal to $\mathrm{f}_{\mathrm{s}}$ of the tension test

TABLE 2. COMPARISON BETWEEN THE PRESENT AND PREVIOUS TESTS

\begin{tabular}{|c|c|c|c|c|}
\hline \multirow{2}{*}{ Field Test } & \multicolumn{2}{|c|}{ Measured } & \multicolumn{2}{|c|}{ Calculated } \\
\hline & $\mathbf{f}_{\mathrm{s}}, \mathbf{k P a}$ & $\mathbf{q}_{\mathrm{p}}, \mathbf{M P a}$ & $\mathbf{f}_{\mathrm{s}}, \mathbf{k P a}$ & $\mathrm{q}_{\mathrm{p}}, \mathrm{MPa}$ \\
\hline $\begin{array}{c}\text { Present Tests } \\
\text { Pile } 0.8 \mathrm{~m} \times 20 \mathrm{~m} \text {, Tension }\end{array}$ & 156 & -- & 120 & -- \\
\hline $\begin{array}{c}\text { Pile } 1.5 \mathrm{~m} \text { dia } \times 35 \mathrm{~m} \text { length } \\
\text { Compression } \\
\end{array}$ & $156^{*}$ & 12.56 initial $^{+}$ & 120 & $\begin{array}{c}19.15(\mathrm{~N}=50), 38.3 \\
(\mathrm{~N}=100)\end{array}$ \\
\hline $\begin{array}{c}\text { Previous Tests } \\
\text { Ismael \& Farrag }(2014) \\
\text { Pile } 1.2 \mathrm{~m} \times 25 \mathrm{~m} \text {, Compression }\end{array}$ & 158 & 8.74 initial $^{+}$ & $\geq 96$ & $\begin{array}{c}19.15(\mathrm{~N}=50) \\
38.3(\mathrm{~N}=100)\end{array}$ \\
\hline Pile $1.2 \mathrm{~m} \times 18 \mathrm{~m}$, Compression & 185 & $4.33 \mathrm{initial}^{+}$ & & \\
\hline $\begin{array}{c}\text { Ismael \& Al-Sanad (1986) } \\
\text { Tension } \\
9 \text { piles } 0.5 \mathrm{~m} \text { diam, } \mathrm{L}=5-10 \mathrm{~m}\end{array}$ & $\geq 107.7$ & -- & $>57$ & -- \\
\hline
\end{tabular}

3. The calculated skin friction based on the standard penetration test $\mathrm{N}$ values, using the classical Meyerhof method was below the measured values assuming the average SPT N measured value of 125 along the pile shaft. On the other hand the calculated base resistance was larger than the measured values. It is $19.15 \mathrm{MPa}$ if $\mathrm{N}=50,38.3 \mathrm{MPa}$ if $\mathrm{N}=100$.

4. For the large bored piles in very dense silty sands of the present study, failure was progressive in nature and the failure load was defined by the slope tangent method.

5. The pile movement at ultimate load were small being $2.56 \%$ for the tension pile and $1.93 \%$ for the compression pile.

\section{Acknowledgment}

The author is grateful to Kuwait Bruckner Construction Contracting Company, Kuwait for providing the test equipment. Thanks to engineer Hani Amin of the Civil

Engineering Department, Kuwait University for his assistance in the data interpretations and for Mrs. Mini Kora for typing the manuscript..

\section{References}

[1] American Society for Testing and Materials Standards (2007) - ASTMD1143/D 1143M-07. American Society for Testing and Materials, Philadelphia, Pa, USA.

[2] N.F. Ismael, "Skin friction of driven piles in calcareous sands". J. Geotech. \& Geoenvir. Engrg. Div., ASCE, 115(1): 135-139, 1989.

[3] N.F. Ismael, "Analysis of load tests on piles driven through calcareous desert sands". J. Geotech. \& Geoenvir. Engrg. Div., ASCE, 125(10): 905-908, 1999.

[4] N.F. Ismael, "Analysis of load tests on large diameter bored piles in very dense cemented sands". Proceedings of the fifteenth Southeast Asian Geotechnical Conference, SEAGC, Bangkok, Thailand, Vol. 1, 2004.

[5] N.F. Ismael and H.A. Al-Sanad, "Uplift capacity of bored piles in calcareous soils". Journal of Geotechnical Engineering, Vol. 112, No. 10: 928-940, 1986.

[6] N.F. Ismael and K. Farraj, "Analysis of load transfer along large diameter bored piles in very dense sands", proceedings of $39^{\text {th }}$ DFI Annual Conference on Deep Foundations, Atlanta, Georgia, USA, pp. 151-159, 2014.

[7] G.G. Meyerhof, "Bearing capacity and settlement of pile foundation", J. of Geotech. Engrg. Div., ASCE, 102(3): 195-228, 1976.

[8] R.B.Peck, W.E. Hanson and T.H. Thornburn, "Foundation Engineering", John Wiley, USA, 1974. 